\title{
OPTIMALISASI PRESTASI BELAJAR MELALUI SIKAP KEMANDIRIAN BELAJAR SISWA SMK JURUSAN MULTIMEDIA
}

\author{
W. W. Setyowati ${ }^{1)}$, Munoto'), L. Anifah ${ }^{3)}$, T. Rijanto4), L. Nurlaela ${ }^{5)}$ \\ ${ }^{12345}$ Pascasarjana, Universitas Negeri Surabaya \\ Email: wiwit.18002@mhs.unesa.ac.id ${ }^{1}$, munoto@unesa.ac.id ${ }^{2}$, lilikanifah@unesa.ac.id ${ }^{3}$, tririjanto@unesa.ac.id ${ }^{4}$, \\ lutfiyahnurlaela@unesa.ac.id ${ }^{5}$
}

\begin{abstract}
ABSTRAK
Pendidikan merupakan suatu sistem yang diciptakan untuk terlaksananya pembelajaran yang terdiri atas proses belajar dan pengajaran dengan harapan dapat mencapai suatu tujuan pembelajaran yang telah ditetapkan. Untuk dapat mencapai tujuan tersebut dapat dilakukan upaya dengan optimalisasi pestasi belajar siswa. Pertanyaan yang diajukan yakni "apakah sikap kemandirian belajar dapat mengoptimalkan prestasi belajar siswa?" dengan tujuan untuk mengetahui apakah sikap kemandirian belajar dapat mengoptimalkan prestasi belajar ditinjau dari hasil belajar siswa. Melalui kajian literatur beberapa referensi dan penelitian yang relevan, analisa hasil penelitian, dan kemudian dilaksanakan focus group discussion. Berdasarkan hasil analisa dan didapatkan kesimpulan bahwa (1) Optimalisasi hasil belajar dapat dilakukan dengan meningkatkan sikap kemandirian belajar siswa khususnya jurusan multimedia; (2) Peningkatan kemandirian belajar siswa dapat dilakukan dengan perencanaan pembelajaran yang lebih mengarah pada penumbuhan sikap belajar secara mandiri baik berbantuan media atau kolaborasi metode pembelajaran yang bervariasi; (3) Pelaksanaan pembelajaran sebagai upaya optimalisasi hasil belajar melalui sikap kemandirian belajar perlu mempertimbangkan berbagai hal seperti kesiapan pembelajaran, sarana prasarana, serta kelengkapan pembelajaran baik pihak sekolah maupun siswa.
\end{abstract}

Kata kunci: Prestasi belajar, sikap kemandirian belajar, siswa SMK

\begin{abstract}
Education is a system created for the implementation of learning which consists of learning and teaching processes with the hope of achieving a predetermined learning goal. To be able to achieve these objectives efforts can be made by optimizing student learning pestasi. The question posed is "whether the attitude of learning independence can optimize student achievement?" With the aim to find out whether the attitude of learning independence can optimize learning achievement in terms of student learning outcomes. Through a literature review some relevant references and research, analysis of research results, and then focus group discussions are carried out. Based on the results of the analysis and concluded that (1) Optimization of learning outcomes can be done by increasing the attitude of student learning independence especially multimedia majors; (2) Increasing the independence of student learning can be done by planning learning that is more directed to the growth of learning attitudes independently either assisted by media or collaborative learning methods that vary; (3) The implementation of learning as an effort to optimize learning outcomes through attitudes of learning independence needs to consider various things such as learning readiness, infrastructure, and completeness of learning both the school and students.
\end{abstract}

Keywords: Learning achievement, learning independence attitude, vocational students 


\section{PENDAHULUAN}

Pendidikan merupakan suatu usaha sadar dan terencana untuk mewujudkan pembelajaran yang aktif dalam mengembangkan potensi peserta didik untuk memiliki kemampuan terkait bidang spiritual, kepribadian, akhlak, serta ketrampilan bidang sosial[1]. Berdasarkan pengertian tersebut dapat dinyatakan bahwa pelaksanaan pendidikan merupakan suatu tindakan terencana yang didesain untuk menciptakan pembelajaran sebagai upaya mencapai tujuan pendidikan. Sedangkan tujuan pendidikan merupakan salah satu tolak ukur keberhasilan dari pelaksanaan pembelajaran, salah satu tujuan pembelajaran yakni tersampaikannya materi pelajaran, adanya perkembangan siswa dalam bidang kognitif, afektif dan psikomotor siswa secara aktif, hingga tercapainya tujuan pendidikan nasional yakni untuk kemajuan pendidikan di Indonesia.

Pentingnya pencapaian tujuan pendidikan menjadikan pendidik harus berperan aktif dan penuh tanggungjawab menjalankan tugasnya. Sebagaimana dalam pencapaian tujuan pendidikan, guru sangat berperan penting karena guru termasuk salah satu komponen pendidikan yang sangat berpengaruh dalam pelaksanaan pembelajaran. Hal tersebut dikarenakan guru merupakan subjek utama yang merencanakan hingga melaksanakan proses pembelajaran yang memungkinkan terciptanya suatu pendidikan. Dalam pelaksanaannya, guru dituntut untuk dapat merencanakan pembelajaran yang baik diantaranya melalui perencanaan desain pembelajaran yang disesuaikan dengan kebutuhan siswa di lapangan dan tujuan pembelajaran yang hendak dicapai. Ditambah lagi dengan adanya perkembangan yang terus berjalan seiring bergantinya waktu. Sebagaimana tujuan pembelajaran yang perlu diperbarui khususnya pembelajaran abad XXI di Indonesia, yakni secara umum harus memenuhi diantaranya (1) melakukan enkulturasi (perubahan) dan akulturasi (penyesuaian) budaya masyarakat untuk belajar memecahkan masalah secara kreatifdan transformatif berbasis budaya tekno-sains-sosio-kultural; (2) mengembangkan kapabilitas kompetensi /skill, tata nilai, norma, mental, budaya kerja masyarakat peserta didik; (3) terampil menjalani dan memenuhi kebutuhan hidup (life skills) diri pribadinya dalam berinteraksi di dunia kerja, keluarga, dan masyarakat sebagai dharma negara; (4) terampil belajar (learning skills) disepanjang hayat ditandai dengan meningkatnya kreativitas berpikir, bekerja kreatif, dan menerapkan inovasi dalam kehidupan nyata; dan (5) terampil menggunakan teknologi, multimedia, dan sistem informasi menuju literasi digital[2]. Adapun ketercapaian tujuan pembelajaran dapat ditinjau dari beberapa hal diantaranya yakni pada hasil belajar siswa atau istilah lainnya prestasi belajar siswa. Jika guru mampu menciptakan pembelajaran yang baik, maka siswa akan mudah dalam memahami materi atau pengetahuan yang telah disampaikan, sehingga hasil belajar yang diperoleh siswa sebagai bukti pemahaman pengetahuan akan sesuai dengan kemampuan siswa tersebut. Sehingga tujuan pembelajaran juga dapat tercapai. Oleh sebab itu, hasil belajar siswa sangat penting sebagai tolak ukur pemahaman siswa.

Pada kenyataannya, hasil belajar yang baik tidak bisa didapatkan dengan mudah, namun perlu adanya perencanaan, bimbingan dan arahan dari guru agar siswa mampu memahami materi yang diajarkan. Namun, hal tersebut juga dapat dipengaruhi oleh berbagai faktor diantaranya faktor intern yang merupakan suatu faktor pengaruh dari dalam diri siswa itu sendiri, sedangkan faktor ekstern merupakan faktor pengaruh dari luar diri siswa. Dalam hal ini yang sangat penting adalah faktor intern, hal tersebut disebabkan faktor ini merupakan faktor yang terbentuk dari dalam diri siswa sendiri, dan sangat berpengaruh besar pada tingkat pemahaman siswa terhadap suatu pengetahuan. Adapun faktor-faktor yang dapat mempengaruhi tersebut dibagi menjadi dua yakni faktor internal dan eksternal. Faktor internal dipengaruhi oleh: (1) Faktor Fisiologis yang berkaitan dengan keadaan fisik seorang individu. Faktor tersebut berpengaruh karena merupakan salah satu kesiapan siswa ketika akan menerima pembelajaran yang pada akhirnya akan mempengaruhi hasil belajar siswa. (2) Faktor Psikologis yang meliputi kemampuan intelegensi, perhatian, minat dan bakat, motivasi, dan kognitif. Sedangkan faktor eksternal yang mempengaruhi hasil belajar yakni (1) faktor lingkungan yang berupa lingkungan fisik dan lingkungan sosial seperti keadaan lingkungan tempat siswa belajar. Sedangkan untuk lingkungan sosial dapat yang berwujud maunisa atau hal-hal lain seperti hiruk pikuk lalu lintas, suara orang yang berkerumun, mesin pabrik, dan lain sebagainya. (2) Faktor Instrumental, yakni faktor yang keberadaan dan penggunaannya dirancang sesuai dengan hasil belajar yang diharapkan yang berupa kurikulum, sarana dan fasilitas, dan guru [3]. Jadi, faktor internal adalah faktor yang berkaitan dengan kondisi fisik seorang individu. Sedangkan faktor eksternal adalah hal yang berkaitan dengan kondisi lingkungan atau sekitar individu tersebut.

Selain faktor internal dan eksternal, masih banyak sekali hal yang harus diperhatikan. Sebagai contoh, Desain pembelajaran yang sangat baik jika tidak mampu membelajarkan siswa maka dapat dipastikan tujuan pembelajaran tidak akan tercapai. Sehingga dalam perencanaan desain pembelajaran sangat perlu untuk memperhatikan faktor-faktor internal siswa, diantaranya seperti 
kemandirian belajar siswa. Kemandirian belajar siswa merupakan salah satu sikap yang dapat mempengaruhi hasil belajar siswa dan termasuk karakter penting dalam perkembangan seorang individu. Sedangkan kemandirian merupakan salah satu proses perkembangan yang penting bagi remaja [4]. Kemandirian diartikan juga sebagai suatu perubahan dalam diri seseorang yang merupakan hasil dari pengalaman dan latihan diri sediri tanpa bergantung pada orang lain [5]. Berdasarkan beberapa pengertian tersebut, peneliti menyimpulkan bahwa kemandirian belajar siswa merupakan sikap belajar yang mampu dilakukan secara individu, dimana sikap tersebut sangat penting dalam upaya pencapaian hasil belajar yang baik. Hal tersebut dikarenakan secara tidak langsung siswa akan dituntut untuk dapat belajar secara mandiri dengan mengeksplor seluruh kemampuannya dalam memahami pengatahuan yang baru. Dengan demikian pembelajaran yang terlaksana akan lebih bermakna dan memungkinkan siswa lebih mudah memahami materi yang diajarkan oleh guru, karena siswa mempelajarinya dan menemukan penjelasan sendiri. Selain itu, pembelajaran mandiri sejalan dengan kurikulum 2013 yang berorientasi pada siswa. Adapun yang dimaksud berorientasi pada siswa adalah segala pembelajaran yang tercipta berpusat pada siswa. Jadi, dalam proses pembelajaran mayoritas didominasi oleh kegiatan siswa. Siswa dituntut untuk lebih aktif dalam pembelajaran. Sedangkan guru sebagai fasilitator dalam pembelajaran. Oleh karena itu, pelaksanaan proses pembelajaran dengan menekankan sikap kemandirian belajar diharapkan mampu meningkatkan prestasi belajar siswa dan sekaligus sebagai upaya implementasi kurikulum 2013.

Berdasarkan pemaparan diatas, dapat diajukan beberapa pertanyaan diantaranya: (1) apa yang dimaksud prestasi belajar?; (2) Adakah keterkaitan sikap kemandirian belajar dengan hasil belajar yang diperoleh siswa?; (3) apakah sikap kemandirian belajar dapat mengoptimalkan prestasi belajar siswa?. Berdasarkan beberapa pertanyaan tersebut, peneliti membatasi penelitian ini hanya terkait pertanyaan nomor (3) yakni "apakah sikap kemandirian belajar dapat mengoptimalkan prestasi belajar siswa?" khususnya pada tingkat pendidikan Sekolah Menengah Kejuruan. Adapun prestasi belajar yang dimaksud dalam penelitian ini adalah hasil belajar siswa. Hal tersebut sejalan dengan pengertian hasil belajar yakni hasil dari suatu interaksi tindak belajar dan tindak mengajar dan merupakan suatu puncak proses belajar [6]. Pengertian lain terkait hasil belajar diartikan sebagai perubahan yang diperoleh peserta didik setelah mengalami kegiatan belajar [7]. Adapun hasil belajar ranah kognitif berkenaan dengan hasil belajar intelektual yang terdiri dari enam aspek, yakni pengetahuan atau ingatan, pemahaman, aplikasi, analisis, sitesis, dan evaluasi. Kedua aspek pertama disebut aspek kognitif tingkat rendah dan keempat aspek berikutnya termasuk kognitif tingkat tinggi.

\section{METODE PENELITIAN}

Penelitian ini dilakukan dengan metode kajian literatur dari referensi dan hasil-hasil penelitian yang relevan, kemudian dilaksanakan "focus group discussion (FGD)". Jadi proses yang dilakukan adalah mengumpulkan beberapa literatur yang sesuai dengan pokok bahasan, kemudian dilakukan pengkajian dan analisa hasil penelitian dan kesesuaian dengan teori-teori yang ada. Dan diakhir dibuat simpulan atas analisa yang ada. Sedangkan referensi dalam penelitian ini merupakan referensi-referensi yang mendukung terkait prestasi belajar siswa yang ditinjau dari hasil belajar siswa dan kemandirian belajar. Sedangkan penelitian yang relevan diantaranya terkait prestasi belajar yang ditinjau dari capaian hasil belajar siswa, tingkat kemandirian belajar siswa, dan peningkatan hasil belajar siswa melalui sikap kemandirian belajar yang dimiliki siswa SMK.

\section{HASIL DAN PEMBAHASAN}

Banyak sekali penelitian yang dilaksanakan terkait prestasi belajar dan kemandirian belajar dengan keberhasilan dalam peningkatan prestasi belajar. Salah satu peneltiian menyimpulkan bahwa: (1) Terdapat pengaruh yang positif dan signifikan antara kemandirian belajar dengan prestasi belajar siswa. (2) Terdapat pengaruh yang positif dan signifikan antara kebiasaaan belajar dengan prestasi belajar siswa. 3) Secara bersama-sama terdapat pengaruh yang positif dan signifikan antara kemandirian belajar dan kebiasaan belajar terhadap prestasi belajar siswa [8]. Berdasarkan kesimpulan penelitian tersebut dapat dinyatakan bahwa prestasi belajar dapat dioptimalkan dengan berbagai upaya melalui peningkatan kemandirian belajar siswa, karena sikap kemandirian belajar terbukti memiliki pengaruh positif terhadap prestasi belajar siswa. Hal tersebut terbukti dengan hasil yang didapat oleh peneliti pada kesimpulan yang pertama menyatakan bahwa kemandirian belajar berpengaruh positif dan signifikan terhadap prestasi belajar siswa. Hal tersebut berarti bahwa siswa yang memiliki kemandirian belajar tinggi akan berpengaruh baik pula pada prestasi belajar siswa. Begitu juga sebaliknya pada siswa yang memiliki kemandirian belajar yang rendah. Jadi, prestasi belajar siswa mengikuti tingkat kemandirian belajar siswa. Sedangkan kesimpulan yang kedua, 
prestasi belajar dikaitkan dengan kebiasaan belajar siswa sehingga didapatkan hasil bahwa kebiasaan belajar juga berpengaruh positif dan signifikan terhadap prestasi belajar sebagai mana kemandirian belajar siswa. Adapun pada kesimpulan ketiga disebutkan bahwa kedua hal tersebut secara bersamaan berpengaruh terhadap prestasi belajar. Sehingga berdasarkan hasil penelitian tersebut, dapat disimpulkan bahwa kemandirian belajar dapat dijadikan sebagai upaya untuk menunjang optimalisasi prestasi belajar. Hasil penelitian lain yang sejalan yakni diperoleh bahwa terdapat hubungan positif antara kemandirian belajar siswa dengan nilai korelasi yakni sebesar 0,579. Hal tersebut menunjukkan bahwa hubungan yang ada tergolong cukup kuat. Dengan kontribusi kemandirian belajar sebesar 33,5\% menjadikan hasil belajar berada pada kategori tinggi [9]. Analisis penelitian tersebut juga dijelaskan bahwa kemandirian belajar termasuk suatu keharusan dalam pembelajaran, sebab kemandirian belajar memiliki peran positif yang cukup tinggi pada hasil belajar.

Pengaruh sikap kemandirian belajar siswa terhadap prestasi belajar juga terbukti dengan adanya perbedaan pengaruh yang signifikan antara siswa yang memiliki tingkat kemandirian tinggi dan siswa dengan kemandirian rendah dengan nilai sebesar 0,007 [10]. Penelitian tersebut membuktikan bahwa ada perbedaan prestasi siswa yang memiliki tingkat kemandirian tinggi dengan siswa dengan kemandirian rendah. Perbedaan prestasi belajar yang didapat dipengaruhi oleh tingkat kemandiran siswa. Siswa dengan kemandirian belajar tinggi akan lebih mudah memahami pembelajaran dengan pendekatan inquiri. Sedangkan siswa dengan kemandirian belajar rendah akan mengalami sedikit kesulitan dalam memahami pembelajaran, karena ia terbiasa mendapatkan bantuan dari guru atau orang lain dalam memahami materi pelajaran. Adapun perbedaan tersebut dapat terjadi karena akibat dari adanya tindakan yang diberikan, sebagaimana hasil belajar dan kemandirian siswa mengalami peningkatan yang cukup signifikan dengan dilakukan treatment penerapan media edmodo [11]. Media edmodo merupakan salah satu media E-learning yang sangat mendukung dan sesuai untuk pembelajaran dengan menekankan sikap kemandirian belajar. Selain itu, penerapan media E-learning tersebut termasuk dalam klasifikasi belajar mandiri. Adapun klasifikasi belajar mandiri dibagi menjadi dua, yakni belajar mandiri secara online dan belajar mandiri secara offline [12]. Dengan penerapan suatu treatment dapat memberikan hasil penelitian yang berbeda, hal tersebut tidak terlepas dari apa yang direncanakan dan dilakukan untuk pencapaian hasil yang diinginkan. Sedangkan perencanaan yang dilakukan dapat mengkolaborasikan berbagai metode, media, dan penggunaan kemampuan afektif yang dapat menunjang peningkatan kemampuan kognitif siswa. Selain bukti adanya pengaruh, dapat diketahui pula tentang hubungan antara kemandirian dan prestasi belajar. Banyak penelitian yang menunjukkan hubungan antara hasil belajar dengan sikap kemandirian. Diantaranya hubungan positif secara signifikan antara kemandirian belajar siswa dengan hasil belajar yakni sebesar 0,400 pada siswa SMK kelas XII [13]. Adanya hubungan antara keduanya merupakan bukti bahwa terdapat keterkaitan, dimana menunjukkan adanya sebab akibat terhadap salah satu hal tersebut. Hasil belajar yang baik merupakan akibat dari adanya kemandirian siswa yang baik.

Penelitian lain terkait hubungan kemandirian belajar siswa dengan prestasi belajar juga menyatakan dengan ketentuan dimana semakin tinggi tingkat kemandirian belajar maka semakin tinggi pula hasil belajar yang diperoleh siswa [14]. Sebaliknya jika semakin rendah tingkat kemandirian belajar maka akan semakin rendah juga hasil belajar siswa. Berdasarkan pemaparan tersebut, dapat disimpulkan bahwa hubungan kemandirian belajar dan hasil belajar siswa berbanding lurus. Penerapan pembelajaran dengan menekankan sikap kemandirian pada jenjang SMK tersebut memberikan bukti adanya keterkaitan yang positif, yakni dari penerapan kemandirian belajar yang mengakibatkan hasil belajar siswa meningkat dan tergolong baik. Tingkat mandiri siswa juga akan mempengaruhi prestasi belajar siswa tersebut [15]. Siswa yang memiliki karater belajar mandiri akan tetap mampu memahami suatu materi dengan baik walaupun tidak ada bantuan dari orang lain. Pengaruh yang muncul juga dapat dibuktikan dengan adanya perbedaan yang bermakna antara kelompok kontrol dan kelompok eksperimen pada suatu penelitian [16]. Terdapat perbedaan antar kelompok pada hasil penelitian tersebut membuktikan bahwa ada pengaruh yang terjadi akibat tindakan pembelajaran yang dirancang terhadap hasil belajar siswa. Perbedaan prestasi belajar juga didapatkan pada prestasi belajar siswa dengan self regulated learning tinggi lebih baik dibandingkan siswa dengan self regulated learning sedang dan rendah. Dan prestasi belajar siswa dengan self regulated learning sedang lebih baik daripada siswa dengan self regulated learning rendah[17].

Adapun kontribusi atau peran kemandirian belajar dalam optimalisasi prestasi juga dapat dikolaborasi dengan hal lain yang mendukung pelaksanaan pembelajaran. Adapun kolaborasi tersebut diantaranya dapat dilakukan dengan variasi pembelajaran menggunakan media tertentu disertai penekanan pada sikap kemandirian belajar siswa. Proses pembelajaran dapat didesain dengan menggunakan media interaktif, serta penekanan pada sikap kemandirian belajar yang 
dioptimalkan untuk peningkatan hasil belajar siswa. Adapun hasil penelitian tersebut menunjukkan bahwa:(1) Hasil belajar siswa dengan pembelajaran metode pengajaran langsung media cisco IT essential virtual desktop lebih tinggi secara signifikan dibanding hasil belajar siswa yang menggunakan metode pengajaran langsung media powerpoint; (2) Hasil belajar siswa dengan berkemandirian belajar yang tergolong tinggi lebih tinggi secara signifikan dibanding hasil belajar siswa yang berkemandirian belajar rendah; dan (3) Terdapat interaksi secara signifikan antara media pembelajaran (Cisco IT Essentials Virtual Desktop dan media powerpoint) dan kemandirian belajar siswa terhadap hasil belajar perakitan komputer di SMKN 12 Surabaya, dan dapat disimpulkan bahwa pembelajaran metode pengajaran langsung media cisco IT essential virtual desktop berpengaruh pada hasil belajar siswa (ranah kognitif, afektif, dan psikomotor) pada mata pelajaran perakitan komputer di SMKN 12 Surabaya [18]. Penelitian tersebut, peneliti mendesain pembelajaran menggunakan media Cisco IT Essentials Virtual Desktop. Media tersebut merupakan salah satu media interaktif yang menuntut siswa untuk dapat menggunakannya secara mandiri dalam melakukan praktik. Sehingga dari media dan sikap yang dibentuk sangat berkesinambungan dan mendukung untuk mempermudah siswa dalam memahami materi, sehingga pada akhirnya hasil belajar akan meningkat menjadi lebih baik dari sebelumnya.

Sebagai upaya optimalisasi hasil belajar siswa, kemandirian belajar siswa dapat diciptakan melalui pelaksanaan pembelajaran dengan model pembelajaran yang bervariasi misalnya menciptakan Kemandirian Belajar Siswa melalui Pembelajaran berbasis Discovery Learning dengan Assessment for Learning, dalam penelitian tersebut pembelajaran yang menekankan kemandirian belajar didesain dengan langkah-langkah pembelajaran berbasis discovery learning diantaranya: (1) Stimulation, pengkondisian pembelajaran pada suatu permasalahan yang mendorong siswa untuk menemukan tujuan pembelajaran; (2) Problem Statement, siswa mengidentifikasi masalah; (3) Data collection, pengumpulan informasi oleh siswa; (4) Data processing, arahan pada siswa dalam pelaksanaan langkah-langkah penyelesaian masalah; (5) Verification, siswa diarahkan untuk melakukan pemeriksaan sebagai pembuktian kebenaran dari jawaban; (6) Generalization, arahan pada siswa untuk menarik kesimpulan hasil verification; dan (7) Penilaian dengan peer assessment, penilaian hasil kerja siswa sesuai rubrik penilaian oleh guru [19]. Langkah-langkah penerapan discovery learning tersebut dapat digunakan sebagai alternatif pembelajaran untuk meningkatkan sikap kemandirian belajar siswa sekaligus sebagai upaya optimalisasi hasil belajar siswa. Berdasarkan langkah-langkah tersebut, kemandirian belajar diharapkan dapat tercipta dari (1) dorongan atau motivasi guru agar siswa tertarik untuk belajar secara mandiri; (2) ketika siswa mulai mengidentifikasi suatu masalah yang dihadapi siswa; (3) ketika siswa mengumpulkan informasi terkait permasalahan, siswa akan mulai belajar secara mandiri; dan (4) dengan arahan yang diberikan oleh guru dalam penyelesaian masalah, pembuktian serta perumusan kesimpulan, siswa akan dituntut untuk dapat memecahkan permasalahannya secara mandiri. Sehingga keadaan tersebut akan memungkinkan munculnya sikap kemandirian siswa dalam belajar.

Kemandirian belajar juga dapat ditingkatkan dengan berbagai teknik. Penggunaan teknik Self Management misalnya, dengan hasil penelitian yang menunjukkan peningkatan skor kemandirian belajar siswa secara signifikan [20]. Peningkatan sikap kemandirian belajar siswa tersebut dapat dipastikan berdampak pada pemahaman belajar siswa yang akan mengalami peningkatan yang signifikan, karena siswa yang memahami materi akan mampu menjawab pertanyaan atau soal yang diberikan dengan benar. Sehingga prestasi belajar siswa akan berada pada kategori yang baik. Beberapa penelitian sejalan juga menyebutkan bahwa kemandirian belajar lebih dominan dalam hal optimalisasi prestasi belajar siswa, karena dengan kemandirian belajar yang dimiliki siswa akan memberikan pemahaman tentang cara memanfaatkan penggunaan sumber belajar yang ada [21]. Dengan dorongan dan arahan guru serta pengkondisian kelas, siswa akan mulai mencoba mengeksplor sikap kemandiriannya untuk dapat memahami materi atau menyelesaikan permasalahan yang dihadapinya.

Adanya desain pembelajaran yang dirancang dengan kolaborasi model, metode serta teknik, dengan kemandirian belajar juga dapat dipengaruhi oleh faktor lain. Adapun faktor tersebut yakni terkait ketersediaan sarana dan prasarana. Sikap kemandirian belajar siswa dan ketersediaan sarana prasarana berpengaruh signifikan terhadap hasil belajar khususnya pada kegiatan praktik yang dilakukan oleh siswa [22]. Oleh sebab itu ketersediaan sarana juga sangat mempengaruhi tingkat kemandirian belajar siswa. Siswa dengan fasilitas sarana yang cukup akan lebih memungkinkan untuk belajar secara mandiri khususnya dalam pelaksanaan praktik, dibandingkan dengan jumlah sarana yang minim atau bahkan harus berkelompok dalam menggunakan suatu sarana tersebut. Sehingga jika penggunaan sarana yang dilakukan secara bersama, maka dapat dipastikan bahwa hal tersebut akan memberikan peluang bagi siswa untuk bekerja dengan orang lain. Dan pada akhirnya, siswa 
tidak akan dapat mengasah kemandirian belajar yang dimiliki. Akan tetapi, ketersediaan sarana dan prasarana saja belum tentu mampu meningkatkan kemandirian belajar siswa. Sehingga perlu faktor lain untuk memungkinkan siswa dapat belajar secara mandiri. Faktor lain yang mungkin dapat mempengaruhi diantaranya kelengkapan sumber belajar. Kelengkapan sumber belajar dan sikap kemandirian belajar berpengaruh signifikan terhadap prestasi belajar siswa [23]. Siswa dengan memiliki sikap kemandirian belajar tinggi akan akan tinggi pula prestasi belajarnya, dan akan semakin memotivasi siswa jika kelengkapan pembelajaran dalam kategori baik. Kelengkapan yang dimaksudkan diantaranya terkait perangkat serta media atau peralatan pembelajaran. Jika keperluan belajar siswa terpenuhi, maka akan sangat membantu serta mempermudah proses belajar siswa.

Inovasi lain untuk optimalisasi hasil belajar diantaranya melalui Pengembangan Modul Administrasi Kepegawaian Berbasis Strategi Pembelajaran Inkuiri Terbimbing [24]. Pelaksanaan pembelajaran tersebut didapatkan hasil belajar yang sangat baik dan modul tersebut terbukti layak dan dapat digunakan dalam upaya peningkatan hasil belajar dan kemandirian siswa. Sehingga dapat dinyatakan bahwa optimalisasi hasil belajar juga dapat dilakukan dengan variasi media atau sumber belajar siswa, karena modul juga termasuk salah satu komponen kelengkapan belajar yang diperlukan oleh siswa. Modul merupakan sumber belajar yang sangat tepat untuk memupuk sikap kemandirian siswa, karena didalamnya banyak terdapat latihan atau praktik yang harus dikerjakan. Selain itu, mayoritas modul dibuat sendiri oleh guru pengajar dimana akan sangat sesuai dengan kondisi dan kebutuhan siswa. Peningkatan kemandirian belajar juga dapat dilakukan melalui faktor dalam diri siswa diantaranya pada karakter yang dimiliki. Karakter yang dikembangkan merupakan karakter yang berkaitan erat dengan sikap mandiri siswa dalam belajar. Diantaranya karakter emosional pada diri siswa. Kecerdasan emosional berpengaruh positif secara signifikan terhadap sikap kemandirian belajar siswa [25]. Pengaruh yang muncul tersebut merupakan akibat dari pengendalian sikap emosional yang muncul dari dalam diri siswa. siswa yang mempu mengendalikan emosionalnya dengan baik, akan mampu belajar dengan tenang. Namun sebaliknya, jika siswa tidak mampu mengendalikan sikap emosionalnya maka ia akan mengalami kesulitan selama memahami materi yang dipelajarinya. Sehingga dapat diartikan bahwa peran kecerdasan emosional juga mampu mempengaruhi sikap kemandirian belajar yang akan berdampak pada prestasi belajar yang diperoleh siswa. Oleh sebab itu, dapat disimpulkan pada penelitian tersebut bahwa desain kolaborasi antara kecerdasan emosional dan kemandirian belajar mampu meningkatkan prestasi belajar yang diperoleh siswa.

Selain beberapa desain pembelajaran tersebut diatas, peningkatan kemandirian belajar dapat dilakukan dengan model pembelajaran lain. Kontribusi lain yakni hasil penelitian yang disimpulkan bahwa terdapat peningkatan secara bertahap pada tiap siklus ke arah lebih baik ditinjau dari nilai rerata presentasi yang semakin meningkat dan baik [26]. Sebagaimana upaya optimalisasi hasil belajar terserbut tidak cukup hanya pada penerapan pembelajaran dengan penekanan sikap kemandirian belajar. Namun perlu diadakan evaluasi atau analisis terkait pelaksanaan pembelajaran. Evaluasi tersebut dilakukan dengan tujuan sebagai timbal balik atas pembelajaran yang telah terlaksana, sekaligus dapat digunakan sebagai dasar penentu perencanaan pembelajaran pada pertemuan selanjutnya. Hasil penelitian lain yang sejalan diantaranya yakni: (1) fasilitas belajar memberikan dampak positif terhadap hasil belajar siswa; (2) kemandirian belajar siswa berpengaruh positif terhadap hasil belajar siswa; (3) fasilitas belajar dan sikap kemandirian belajar siswa bersamasama memiliki pengaruh positif terhadap hasil belajar; dan (4) hasil belajar tidak sepenuhnya dipengaruhi oleh fasilitas belajar dan kemandirian belajar saja, namun dapat dipengaruhi variabel lain yang tidak diteliti. Sehingga dalam peningkatan kemandirian belajar siswa agar hasil belajar lebih optimal perlu memperhatikan segala aspek komponen belajar dimana kelengkapan komponenkomponen tersebut juga sangat penting untuk optimalisasi hasil belajar [27]. Berdasarkan evaluasi tersebut terbukti bahwa kemandirian belajar dapat meningkatkan hasil belajar, sebagaimana akibat yang terjadi setelah pembelajaran yakni adanya pengaruh positif antara kemandirian belajar siswa dengan hasil belajar.

Adapun upaya peningkatan kemandirian belajar siswa dapat juga ditinjau dari motivasi belajar siswa atau hasil belajar siswa. Peningkatan hasil belajar siswa tergolong tinggi dengan penerapan pembelajaran e-learning berbasis edmodo yang memberikan dampak peningkatan motivasi siswa dan hasil belajar siswa [28]. Berdasarkan peningkatan motivasi dan hasil belajar tersebut, dapat dinyatakan bahwa kemandirian belajar siswa akan berbanding lurus dengan kedua hal tersebut, karena peningkatan yang terjadi merupakan dampak penerapan e-learning serta termasuk implementasi dari pembelajaran berorientasi pada kemandirian belajar siswa. Dengan bantuan edmodo, siswa dituntut untuk memahami materi secara mandiri. Selain itu, penggunaan aplikasi yang 
baru dan berbeda dari biasanya mampu menjadikan siswa lebih tertarik dan termotivasi dalam belajar. Sehingga siswa akan lebih terdorong untuk belajar secara mandiri.

Kemandirian belajar sangat dibutuhkan dan sesuai diterapkan pada siswa jenjang SMK. Hal tersebut disebabkan dengan tuntutan yang harus dipenuhi siswa khususnya dalam hal persiapan diri didunia kerja. Adanya kompetensi inti tertentu pada tiap bidang keahlian menjadikan kemandirian belajar semakin diperhatikan dan difokuskan untuk penunjang peningkatan kompetensi siswa. Pendidikan tingkat SMK khususnya kompetensi inti bidang keahlian teknologi informasi dan komunikasi, program keahlian teknik komputer dan informatika jurusan multimedia yang membahas terkait kompetensi multimedia terdapat beberapa mata pelajaran produktif diantaranya: (1) Simulasi dan Komunikasi Digital; (2) komputer dan jaringan; (3) Pemrograman dasar; (4) Dasar Desain Grafis; (5) Desain Grafis Percetakan; (6) Desain Media Interaktif; (7) Animasi 2D dan 3D; dan (8) Teknik Pengolahan Audio dan Video [29]. Beberapa mata pelajaran inti tersebut sangat membutuhkan kemampuan individual dan menuntut kemandirian belajar yang cukup tinggi. Hal tersebut dikarenakan hampir seluruh mata pelajaran perlu dipahami dengan kemampuan masing-masing individu terkait kreatifitas. Seperti pada mata pelajaran simulasi dan komunikasi digital, siswa dituntut untuk dapat melakukan suatu sumulasi dan komunikasi secara digital. Sehingga kemandirian belajar siswa sangat dibutuhkan dalam pemahaman materi tersebut. Mengingat kemampuan masing-masing individu sangat berpengaruh dalam segala hal khususnya untuk pemecahan masalah yang dihadapi, baik permasalahan dalam pembelajaran maupun ketika pelaksanaan praktik kerja industri.

Berdasarkan beberapa hasil penelitian dan analisa tersebut diatas, dapat disimpulkan bahwa kemandirian belajar berpengaruh secara positif dan signifikan dalam peningkatan prestasi belajar siswa. Peningkatan tersebut sebagaimana yang dinyatakan oleh Serdyukov (2013) berdasarkan hasil penelitiannya "Flying with Clipped Wings: Are Students Independent in Online College Classes?" yang mengatakan bahwa peningkatan persiapan siswa untuk keberhasilan akademik dapat dilakukan dengan sikap kemandirian dalam belajar [30]. Oleh karena itu, untuk meningkatkan prestasi belajar dan sebagai upaya peningkatan tersebut. Kemandirian belajar dapat ditingkatkan untuk dapat meningkatkan prestasi belajar pada jurusan multimedia. Banyak sekali pembelajaran secara mandiri yang dapat dilakukan dalam upaya untuk peningkatan prestasi belajar jurusan multimedia dengan kemandirian belajar. Hal tersebut semakin memungkinkan karena dalam jurusan multimedia sangat memungkinkan pembelajaran dilakukan secara mandiri. Sebab, banyak sekali materi atau mata pelajaran yang membutuhkan tingkat kreatifitas dan kemandirian siswa yang tinggi. Dengan banyaknya materi terkait desain yang menekankan pada kemampuan indivdual siswa, sehingga kemandirian belajar siswa akan sangat berpengaruh terhadap tingkat prestasi belajar siswa. Adapun konsep kemandirian belajar dapat ditandai dengan adanya kemampuan untuk (1) berpikir kritis, kreatif, dan secara inovatif; (2) menemukan identitas diri individu; (3) inisiatifatif dalam setiap langkah kegiatannya; (4) membuat pertimbangan dan tanggapan dalam tindakannya; (5) bertanggung jawab atas semua yang telah dilakukan; (6) memenuhi kebutuhannya sendiri; dan (7) tingkat ketekunan dan disiplin yang baik [31]. Dan pada akhirnya penekanan tingkat kemampuan kemandirian belajar siswa tersebut sangat tepat untuk meningkatkan prestasi belajar yang dimiliki oleh siswa.

Berdasarkan beberapa hasil analisis yang telah dilakukan, dapat disimpulkan bahwa optimalisasi hasil belajar dapat dilakukan dengan meningkatkan sikap kemandirian belajar melalui berbagai langkah seperti (1) Perencanaan pembelajaran yang lebih mengarah pada penumbuhan sikap belajar secara mandiri, baik berbantuan media atau kolaborasi metode pembelajaran yang bervariasi; (2) Perlu adanya pertimbangan sarana prasarana serta kelengkapan pembelajaran lainnya baik dari pihak sekolah maupun siswa; dan (3) perlu adanya evaluasi pembelajaran sebagai timbalbalik dan tindaklanjut dari pelaksanaan proses pembelajaran. Hal tersebut sangat dapat diterapkan di tingkat SMK khususnya pada jurusan multimedia. Dengan tuntutan pemahaman terkait desain yang cukup tinggi, dan seringnya praktik yang disertai dengan penggunaan aplikasi-aplikasi menjadikan sikap kemandirian belajar sangat dibutuhkan oleh siswa. Peningkatan kemandirian belajar siswa sangat berkontribusi tinggi dalam optimalisasi prestasi belajar. Hal tersebut dikarenakan dalam desain sangat diutamakan kemampuan individual siswa, dimana siswa dituntut untuk aktif pada proses belajarnya sendiri. Siswa yang mandiri secara umum akan berpartisipasi secara aktif pada proses belajar mereka sendiri [32]. Siswa tersebut akan berusaha menyelesaikan tugas atau permasalahan yang dihadapinya dengan menggunakan seluruh kemampuan yang ia miliki. Hal tersebut yang sering dikatakan sebagai kemandirian belajar siswa. Dengan kemandirian belajar yang tinggi, siswa mampu belajar sendiri tanpa mendapatkan bantuan dari orang lain dan kemampuan yang didapatkan sendiri akan lebih mudah untuk dimengerti dibandingkan dengan pengetahuan yang disajikan secara langsung oleh orang lain. Sehingga dalam hal ini, kemandirian siswa sangat dibutuhkan sebagai upaya meningkatkan prestasi belajar siswa. Pentingnya kemandirian belajar juga 
dikemukakan oleh Tanriseven, bahwa sikap kemandirian belajar merupakan aspek penting dalam pencapaian dan kesuksesan akademik.

Penjelasan tersebut sebagaimana dengan hasil focus group discussion bahwa dalam pembelajaran jurusan multimedia sangat membutuhkan sikap kemandirian belajar. Hal tersebut disebabkan indikator pembelajaran pada jurusan multimedia yang sangat sesuai dan terdukung dengan adanya sikap kemandirian siswa dalam belajar. Materi jurusan multimedia yang mayoritas terkait desain grafis menuntut siswa untuk belajar secara mandiri, terlebih dalam mengeksplor kemampuan desain dan kreatifitas yang dimiliki. Sehingga, sikap kemandirian belajar sangat dibutuhkan dalam pembelajaran desain grafis yakni pada jurusan multimedia. Adapun dalam upaya menumbuhkan atau meningkatkan sikap mandiri siswa ketika belajar dapat dilakukan dengan berbagai cara, diantaranya dengan (1)mendesain pembelajaran yang memungkinkan siswa dapat belajar secara mandiri, dengan penggunaan model atau metode pembelajaran yang berorientasi siswa secara individu; (2) mempersiapkan serta mengkondisikan perangkat belajar siswa sehingga pembelajaran yang terlaksana dapat berjalan dengan optimal; serta selalu dilakukan evaluasi dan perbaikan pelaksanaan pembelajaran dari waktu ke waktu tiap pertemuan sehingga menjadi lebih baik dari sebelumnya.

\section{SIMPULAN DAN SARAN}

Berdasarkan kajian literatur beberapa referensi dan penelitian yang relevan, hasil analisis, dan serta focus group discussion (FGD), diperoleh kesimpulan bahwa: (1) Optimalisasi hasil belajar dapat dilakukan dengan meningkatkan sikap kemandirian belajar siswa khususnya jurusan multimedia; (2) Peningkatan kemandirian belajar siswa dapat dilakukan dengan perencanaan pembelajaran yang lebih mengarah pada penumbuhan sikap belajar secara mandiri baik berbantuan media atau kolaborasi metode pembelajaran yang bervariasi; (3) Pelaksanaan pembelajaran sebagai upaya optimalisasi hasil belajar melalui sikap kemandirian belajar perlu mempertimbangkan berbagai hal seperti kesiapan pembelajaran, sarana prasarana, serta kelengkapan pembelajaran baik pihak sekolah maupun siswa. Selain hal tersebut, pelaksanaan pembelajaran juga harus memperhatikan kondisi dan kebutuhan siswa. Sebab kondisi siswa sangat berpengaruh pada tindakan yang akan diberikan, dan akan memberikan dampak yang berbeda terkait tindakan yang telah diberikan.

Paparan penjelasan tersebut diatas telah memberikan gambaran terkait pentingnya sikap kemandirian belajar khususnya pada siswa jurusan multimedia. Serta berdasarkan hasil penelitian yang telah ada, peningkatan sikap kemandirian siswa dalam belajar sangat sesuai diterapkan untuk meningkatkan prestasi belajar siswa. Sebagaimana tuntutan ketuntasan belajar siswa pada jurusan multimedia yang lebih mengasah kemampuan individual siswa khususnya kreatifitas dalam mendesain. Sikap kemandirian belajar sangat berkontribusi dalam peningkatan prestasi belajar. Sehingga diharapkan para guru mulai meningkatkan atau menumbuhkan sikap kemandirian siswa dalam belajar, agar siswa dapat belajar secara mandiri dan lebih mudah dalam memahami pembelajaran. Sebab, dengan belajar mandiri atau menemukan pengetahuan sendiri menjadikan pemahaman tersebut lebih bermakna dalam diri siswa. akan tetapi, dalam pelaksanaannya tidak terlepas dari dukungan berbagai pihak baik guru, pemrintah dan dinas untuk memberikan arahan serta pelatihan terkait kemandirian belajar agar guru dapat optimal dalam penumbuhan sikap kemandirian siswa.

\section{UCAPAN TERIMA KASIH}

Penelitian ini dilaksanakan tidak terlepas dari bantuan pihak lain sehingga pada akhirnya dapat terselesaikan tepat waktu. Oleh sebab itu, saya mengucapkan terimakasih kepada dosen pembimbing yang membimbing dan memberikan arahan dalam penyelesaian jurnal ini, saya sampaikan juga terima kasih kepada dosen pengampuh mata kuliah seminar PTK yang telah memberikan saran pada jurnal ini, serta tak teman-teman S2 PTK2018 yang telah ikut memberikan ide dan pemikiran dalam pembuatan jurnal. Semoga hasil penelitian ini dapat bermanfaat bagi kita semua khususnya untuk pendidikan vokasi di Indonesia.

\section{DAFTAR PUSTAKA}

[1] Undang-Undang Republik Indonesia (UURI) Nomor 20 Tahun 2003 tentang sistem pendidikan nasional.

[2] Sudira, Putu. 2018. Pembelajaran Abad XXI Inovasi Teori dan Praksis. Yogyakarta: UNY Press. Hal. 57-58.

[3] Munadi, Yudhi. Media Pembelajaran (Sebuah Pendekatan Baru) Jakarta: Gaung Persada Press, 2012. 
[4] Soesens, B., Vansteenkiste, M., Lens, W., Luyckx, K., Goossens, L., Beyers, W., \& Ryan, R. M. "Conceptualizing parental autonomy support: Adolescent perceptions of promotion of independece versus promotion of volitional functioning," Developmental Psychology, 43(3), 633-646.

[5] Ghofur, Abdul. "Pengembangan Instrumen Kemandirian Belajar Siswa”, Institut Agama Islam Negeri Surakarta.

[6] Dimyati \& Mudjiono. Belajar dan Pembelajaran. Jakarta: Rineka Cipta, 2013.

[7] Maulana Izzudin, Ahmad. (2013). Efektivitas Penggunaan Media Pembelajaran Video Interaktif untuk Meningkatkan Hasil Belajar Praktik Service Engine dan Komponenkomponennya. Universitas Negeri Semarang.

[8] Rusmiyati. Pengaruh Kemandirian dan Kebiasaan Belajar Terhadap Prestasi Belajar Metematika Siswa Kelas X SMA Negeri 1 Rongkop.

[9] Rijal, Syamsu dan Suhaedir Bachtiar. "Hubungan antara Sikap Kemandirian Belajar, dan Gaya Belajar dengan Hasil Belajar Kognitif Siswa," Jurnal BIOEDUKATIKA Vol. 3 No. 2.

[10] Supriyanto. Pengaruh pembelajaran dengan pendekatan inquiri, dan ekspositori terhadap prestasi belajar pendidikan kewarganegaraan ditinjau dari kemandirian siswa (suatu studi di SMAN kabupaten Wonogiri). Tesis. Universitas Sebelas Maret, 2009.

[11] Rifqah, "Meningkatkan Sikap Kemandirian dan Hasil Belajar Siswa pada Mata Pelajaran PPKn melalui Penerapan Media Edmodo Kelas XI A Multimedia SMK Negeri 1 Banjarmasin", LENTERA Jurnal IImiah Kependidikan. Vol 13 No. 2 Hal. 76-86.

[12] Ana Setyarini, Tri. 2016. E-Learning Model to Solve the Problem for Learning Programming. Proceedings of International Research Clinic \& Scientific Publications of Educational Technology.

[13] Julaecha, Siti dan Abdul Baist. "Hubungan Kemandirian Belajar dengan Hasil Belajar Siswa SMK Kelas XII pada Pelajaran Matematika”, Jurnal Analisa 5 (2) Hal 103-108.

[14] Handayani, Novia dan Fauziah. "Hubungan Kemandirian terhadap Hasil Belajar Siswa Mata Pelajaran Matematika di Kelas X SMK Kota Cimahi," Journal ON Education. Vol. 01. No. 02. Hal. 1-8.

[15] Rahmayani, Fadillah. "Hubungan antara Karakter Mandiri Belajar dengan Hasil Belajar Siswa," Jurnal Pendidikan Edutama. Vol. 6 No. 2 Hal. 87-94.

[16] Tanriseven, I. "A Tool That Can Be Effective in the Self-regulated Learning of Pre-service Teacher: The Mind Map. Australian Journal of Teacher Education," 39(1).

[17] Miatun, Asih. 2015. Eksperimentasi model pembelajaran discovery learning, problem solving dan think pair share (tps) pada materi bangun ruang sisi datar ditinjau dari self regulated learning siswa kelas viii smp negeri se-kabupaten Boyolali tahun pelajaran 2014/2015. Universitas Sebelas Maret.

[18] Arief Widarsa, Yohanes. 2018. Pengaruh Penggunaan Media Cisco IT Essentials Virtual Desktop dan Kemandirian Belajar terhadap Hasil Belajar pada Mata Pelajaran Perakitan Komputer di SMK Negeri 12 Surabaya. Tesis. Universitas Negeri Surabaya.

[19] Puji Wulandari, Setyati. Menciptakan Kemandirian Belajar Siswa melalui Pembelajaran berbasis Discovery Learning dengan Assessment for Learning. Jurnal UNS.

[20] Nihe, Jenny Ana. (2017). Pengaruh Teknik Self Management terhadap Kemandirian Belajar Siswa SMK Negeri 1 Makassar. Tesis. Universitas Negeri Makassar.

[21] Putriningrum, Rahajeng. 2011. Hubungan Pemanfaatan Sumber Belajar dan Kemandirian Belajar dengan Prestasi Belajar Mahasiswa D III Kebidanan Kusuma Husada Surakarta. STIKes Kusuma Husada Surakarta.

[22] Mujisuciningtyas, Nunuk. "Pengaruh Kemandirian Belajar dan Sarana Prasarana Pembelajaran terhadap Hasil Belajar Praktik di SMK Negeri 2 Tuban," Jurnal Ekonomi Pendidikan dan Kewirausahaan. Vol 2. No. 1. Hal . 103-115.

[23] Gustini, Eni. 2011. Pengaruh Kelengkapan Sumber Belajar dan Kemandirian terhadap Prestasi Belajar IImu Pengetahuan Sosial Siswa SMP Negeri 10 Prabumulih.

[24] Swandhana, Kharisma, Madziatul Churiyah dan Lohana Juariyah. "Meningkatkan Kemandirian Belajar dan Hasil Belajar Siswa melalui Pengembangan Modul Administrasi Kepegawaian Berbasis Strategi Pembelajaran Inkuiri Terbimbing," Jurnal Pendidikan Bisnis dan Manajemen. Universitas Negeri Malang. Vol. 2. Nomor3. Hal 161-169.

[25] Afero, Baghdad dan Adman. "Peran Kecerdasan Emosional sebagai Faktor yang Mempengaruhi Kemandirian Belajar Siswa," Jurnal Pendidikan Manajemen Perkantoran. Vol. 1, No. 1. Hal. 215-223. 
[26] Mayasari, Finda. (2016). Upaya Meningkatkan Kemandirian Belajar melalui Penerapan Blended Learning berbantu Quipper School Siswa SMK Negeri 1 Surakarta. Universitas Sebelas Maret.

[27] Siti Soleah, Lia. (2017). Analisis Fasilitas Belajar dan Kemandirian Belajar Siswa terhadap Hasil Belajar Prakarya dan Kewirausahaan pada Siswa kelas X SMK Muhammadiyah 1 Sukoharjo Tahun Ajaran 2016/ 2017. Universitas Muhammadiyah Surakarta.

[28] Dewi Purnama Aisiyah, Yossy; dkk, (2017). Penerapan E-Learning berbasis Edmodo pada materi Sistem Koordinasi untuk Meningkatkan Motivasi dan Hasil Belajar Siswa. Prosiding. Universitas PGRI Semarang.

[29] Keputusan direktur jenderal pendidikan dasar menengah tentang kompetensi inti bidang keahlian teknologi informasi dan komunikasi, program keahlian teknik komputer dan informatika.

[30] Serdyukov, Peter. "Flying with Clipped Wings: Are Students Independent in Online College Classes?. Journal of Research in Innovative Teaching," Vol. 6, Issue 1.

[31] Prayekti. "The Influence of Cognitive Learning Style and Learning Independence on the Student' Learning Outcomes," Canadian Center of Science and Education. Vol. 8, No. 2.

[32] Zimmerman, B. J.. "A Social Cognitive View of Self-RegulatedAcademic Learning," Journal of Educational Psychology, 81(3), 1-23. 